\title{
Relationship between the pea crab Pinnixa tumida and its endobenthic holothurian host Paracaudina chilensis
}

\author{
Satoshi Takeda*, Seiichi Tamura, Masahiko Washio \\ Marine Biological Station, Tohoku University, Asamushi, Aomori 039-35, Japan
}

\begin{abstract}
The ecology of the pea crab Pinnixa tumida living in the endobenthic holothurian Paracaudina chilensis, which buries its body in the fine sandy bottom in the sublittoral zone, was investigated. Almost all of the pea crabs collected from their host holothurians were mature females. Mature pea crabs were found to live singly in the alimentary canal of the larger hosts, which are mainly distributed just below the low water level of the spring tide. However, immature crabs were not found in either large or small hosts. In the laboratory, mature crabs searched for the tip of the host's tail, which appeared on the sand's surface, and then entered the host's alimentary canal through the opening of the anus at the tail's tip. These results indicate that the pea crab enters larger hosts only when it is mature, or just before maturity. Pea crabs showed 2 types of feeding preference in the laboratory: suspended particles and the mucus secreted in the alimentary canal of the host. Ovigerous females were found in the hosts between late February and mid-May, carrying eggs which developed slowly and synchronously with those of almost all of the other ovigerous females observed throughout this period, indicating that the pea crab has an annual breeding cycle. The biology of the pea crab was compared with that of crabs living in bivalves and on irregular echinoids.
\end{abstract}

KEY WORDS: Pinnotherid crab - Pinnixa tumida - Symbiosis Host holothurian - Entering behavior . Feeding habit

\section{INTRODUCTION}

The brachyuran family Pinnotheridae (Crustacea) consists of 252 species with various modes of life, i.e. free-living species and species living in bivalves, gastropods, holothurians or tunicates and on echinoids, along with polychaetes or burrowing shrimps, through the whole or a part of their post-larval life (e.g. Wells 1940, Schmitt et al. 1973, Sakai 1976). They are considered to have acquired new life modes through modifications of their own morphology, physiology, reproduction and behavior, and to have been successful in this respect (Bell \& Stancyk 1983). Among the pinnotherid crabs which associate with various types of host organisms, clarification of the symbiotic relationships of these species may be useful for understanding the process of speciation in this group.

·E-mail: stakeda@mail.cc.tohoku.ac.jp
Several investigators have studied, ecologically or behaviorally, the relationships between pinnotherid crabs and their hosts, e.g. crabs living in the mantle cavity of bivalves (Atkins 1926, Stauber 1945, Christensen \& McDermott 1958, Kruczynski 1975), the pallial grooves of chitons (Webster 1968), the burrowtubes of polychaetes (Gray 1961), or on echinoids (Telford 1978a, b, 1982, Bell \& Stancyk 1983, Bell 1984, 1988). In particular, for the genus Dissodactylus living on sand dollars, phylogenetic relationships have been analyzed on the basis of morphological characters (Griffith 1987) or the morphology of mouth parts and feeding behavior (Telford 1982). However, the species inhabiting holothurians have hardly been investigated ecologically or behaviorally, except for a brief description by Wells \& Wells (1961).

The pea crab Pinnixa tumida, described by Stimpson (1858) based on females collected at Hakodate in north Japan, has not been studied ecologically except for a 
report by Yokoya (1928) indicating that the crabs were found in the cloacal cavity of the endobenthic holothurian Paracaudina chilensis and that the female crabs were slightly larger than the males.

In Mutsu Bay in north Japan, host holothurians of this crab live in the fine sandy bottom of the sublittoral zone, where they bury their bodies obliquely (Yamanouchi 1926). The host reaches a maximum of about $17 \mathrm{~cm}$ in length from its mouth to the anus at the tip of its tail (Yamanouchi 1929b). The mouth is buried about $20 \mathrm{~cm}$ below the surface of the sand (Yamanouchi 1926), and the holothurian feeds on the substratum directly (Yamanouchi 1929a, b). The tip of the tail, about $5 \mathrm{~mm}$ in diameter, reaches the surface of the sandy bottom, and excrement, consisting mainly of fine sand from which the food component has been extracted and seawater used for respiration, is expelled as a jet from the anus (Yamanouchi 1929b). Typically, on calm days, a conical concavity is formed in the sandy surface above the mouth, and a conical mound is formed at the tail end with the tip of the tail in the center (Yamanouchi 1926). In general, larger holothurian individuals dominate the shallow bottom just below the spring low tide level, while smaller individuals are distributed in deeper water (Yamanouchi 1926).

The ecology and behavior of the pinnotherid crab inhabiting this holothurian may provide clues for understanding the diversity of the Pinnotheridae. In the present study, the general ecology of this pea crab was investigated by collection of host holothurians in the field. Moreover, the behavior of the pea crab in entering its host, and also its feeding behavior, were observed in the laboratory and compared with behavior of other pea crabs inhabiting bivalves or echinoids.

\section{MATERIALS AND METHODS}

Field survey. Host holothurians were collected at random in the sublittoral fine sandy bottom of Mutsu Bay, inshore Tuchiya, Hiranai, in Aomori Prefecture, northern Japan $\left(40^{\circ} 54^{\prime} \mathrm{N}, 140^{\circ} 52^{\prime} \mathrm{E}\right.$ ). On each sampling occasion from November 1991 to January 1993, more than 30 individual hosts were dug out carefully from the sandy bottom just below the spring low tide level and immediately put separately into polyethylene bags. In addition, 4 times from 1993 to 1994, on a quarterly basis, the holothurians were collected from deeper sandy bottoms, where smaller individuals predominated.

After the alimentary canal of the host had been cut open in the laboratory, its contents, consisting mainly of fine sand and seawater (which were about 4 times the wet weight of the body after removal of the contents of the alimentary canal), were washed out, the surface of the host was wiped with a towel, and the individual's wet weight was recorded. The contents of the alimentary canal and material excreted into the polyethylene bag during transport and storage were preserved in $70 \%$ ethanol. Occasionally the captured holothurian would excrete a pea crab among the fine sand and water before its alimentary canal had been opened. The preserved intestinal contents were passed through a $0.5 \mathrm{~mm}$ mesh sieve, and any pea crabs remaining on the sieve were collected under a stereoscopic microscope.

The sex of each pea crab collected was recorded, and the maximum carapace width was measured with a caliper. The developmental stages of the eggs attached to pleopods of ovigerous females were recorded according to a modification of the scheme of Jones (1980): Stage I, newly deposited eggs with orange yolk present over all the surface; Stage IIa, white tissue cap present in less than half of the surface; Stage IIb, white tissue cap present in more than half of the surface; Stage Illa, black chromatophores present; Stage IIIb, black chromatophores and eyes present; Stage IV, only egg membrane remaining after hatching of zoea, with some Stage IIIb eggs still present. Eggs were counted, and the diameters of 50 eggs were measured randomly. In addition, the sex of the hosts was recorded based on microscopical observation of the gonad morphology; the female host has orange or red gonads containing spherical oocytes, while the male has yellow gonads not containing obvious spherical structures (Tadokoro \& Watanabe 1928).

Air and seawater temperatures and salinity were recorded at 10:00 $\mathrm{h}$ twice a month from November 1991 to January 1993.

Entrance into the host. In order to clarify the process and timing of the entrance of the pea crab into its host, the following observations were carried out. Mature host holothurians were collected in the field and immediately placed and kept in glass vessels without sand. Pea crabs were extracted from host holothurians, and holothurians from which pea crabs had been removed were released into glass vessels $(20.5 \times 22.5 \times 29 \mathrm{~cm}$ deep) containing $15 \mathrm{~cm}$ sea sand and $5 \mathrm{~cm}$ stationary seawater above the sand surface. Hosts usually buried their bodies in the sand about 20 min after release. After $1 \mathrm{~d}, 1$ or 2 pea crabs were released into the vessel, and their movement recorded for 1 s at 1 min intervals with an $8 \mathrm{~mm}$ video camera under continuous light conditions at room temperature $\left(10\right.$ to $\left.22^{\circ} \mathrm{C}\right)$. The process of entrance of the pea crab into its host (which either did or did not already have another crab in its alimentary canal) was observed by playing back the recorded video tapes, and the time of the beginning of insertion of the dactyli of the walking legs of one side and/or the time of the end of entrance of those on the 
opposite side was also recorded. The durations of the simultaneous stay of 2 pea crabs in a single host were recorded. Vessels which were small relative to the size of the host holothurians were used to restrict the movement of the hosts and to enable the process of crab entrance to be recorded in detail.

In addition, the behavior of pea crabs and hosts was observed in a vessel containing seawater only.

Feeding behavior and feeding habit. To examine the feeding habit of the pea crab, various food sources were provided for the crabs in the glass vessels, either directly or indirectly ('indirect' food was separated from the crab by a $5 \mathrm{~mm}$ mesh size net to allow passage of food odor only), and their behavior was observed. The food sources were (1) suspended particles provided just after collection near the shore using plankton nets, (2) living individuals of the bivalve Mactra chinensis, which inhabits the sandy bottom occupied by the host holothurians, or their fresh soft bodies just after dissection, (3) living individuals of the bivalve Mytilus edulis galloprovincialis, which inhabits littoral rocks, or their fresh soft bodies, (4) living individuals of the host holothurians, or their fresh meat, and (5) living individuals of the non-host holothurian Apostichopus japonicus, which inhabits the boulder sea bottom.

\section{RESULTS}

\section{Field survey}

Air and seawater temperatures were lowest in late February, then increased gradually, and reached their maxima in late August and late September, respectively (Fig. 1). Salinities were between 31 and $34 \%$, except in April and May (Fig. 1). The low salinity in April and May is thought to be caused by the inflow of melting snow into Mutsu Bay in spring

Only a single pea crab was found in each inhabited holothurian host. Therefore, the spatial pattern was shown to be uniform by analysis using Morisita's Idindex method ( $\mathrm{p}<0.01$ ) (Morisita 1959). On average, about $35 \%$ of the host holothurians collected from the shallower bottom were inhabited (Fig. 1). The proportion of hosts inhabited tended to be higher when female crabs were ovigerous, and lower when only nonovigerous female crabs were found. The ratio of male to female crabs inhabiting hosts was only 0.07 (Table 1 ).

The sex ratio of hosts collected from the shallower bottom was near 1.0 (Table 1). The frequencies with which male and female hosts were inhabited did not differ significantly $\left(\chi^{2}\right.$-test, $\left.\mathrm{p}>0.05\right)$ (Table 1 )
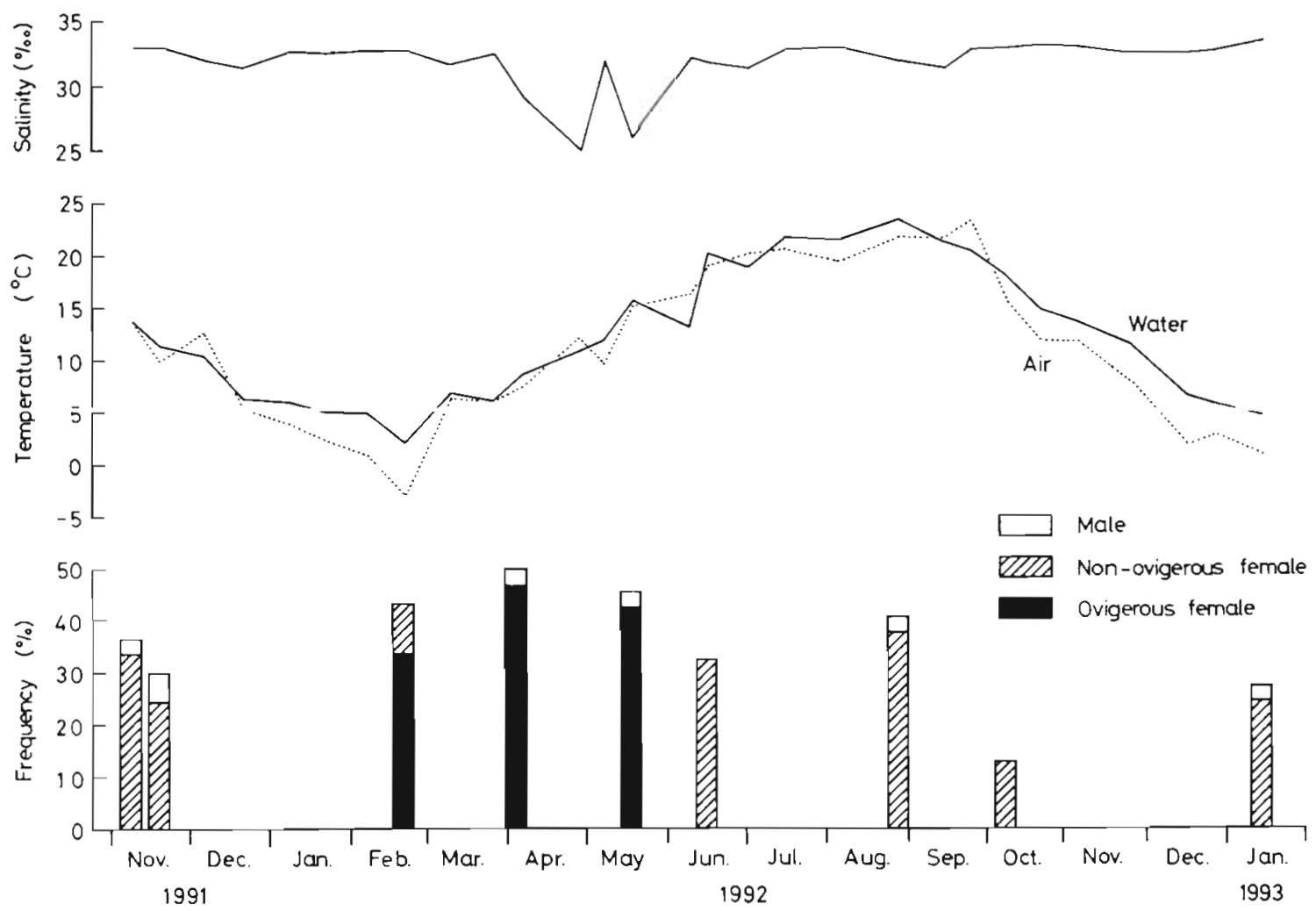

Fig. 1 Seasonal variation of salinity and air and seawater temperatures at the sampling site; and, the proportions of holothurian Paracaudina chilensis inhabited by pea crab Pinnixa tumida collected from the sandy bottom just below the low water level of the spring tide where larger hosts predominated 
Table 1. Relationship between sex of host holothurian Paracaudina chilensis and rate of habitation by pea crab Pinnixa tumida. Holothurians were collected from the sandy bottom just below the water level of the spring tide, where larger hosts predominated. Sex of inhabitants indicates the number of pea crabs of each sex found inhabiting the holothurians. $\chi^{2}$-test $=0.0592, \mathrm{df}=2,0.950<\mathrm{p}<0.975$

\begin{tabular}{|lcccc|}
\hline Sex of host & $\begin{array}{c}\text { No. of hosts } \\
\text { examined }\end{array}$ & $\begin{array}{c}\text { No. of hosts } \\
\text { inhabited }\end{array}$ & $\begin{array}{c}\text { Habitation } \\
\text { rate }\end{array}$ & $\begin{array}{c}\text { Sex of } \\
\text { inhabitants }\end{array}$ \\
\hline Male & 142 & 49 & 0.35 & 5 male, 44 female \\
Female & 14.1 & 51 & 0.36 & $\begin{array}{c}\text { 2 male, } 49 \text { female } \\
1 \text { female }\end{array}$ \\
Indistinguishable & 3 & 1 & 0.33 & $\begin{array}{c}\text { f male, 94 female } \\
\text { Total }\end{array}$ \\
\hline
\end{tabular}

males, as was observed by Yokoya (1928). All the pea crabs collected, except for 1 female with a semi-hard shell, had hard, calcified shells.

Ovigerous female crabs were observed between late February and mid-May (Figs. 1 \& 3). Although the number of eggs in a clutch $(y)$ varied widely among ovigerous females, it showed a weak tendency to increase with increasing carapace width $(x)$ (Fig, 4; $y=-1152.8+193.4 x, \mathrm{n}=37, \mathrm{r}=$ $0.2201, p>0.05$ ). In addition, no significant relationship was recognized

The wet weight of host holothurians collected from the shallower bottom was between 1.94 and $39.49 \mathrm{~g}$, with a mean of $22.19 \mathrm{~g}$ (Fig. 2). Hosts inhabited by male pea crabs had wet weights of between 24.51 and $34.68 \mathrm{~g}$, while those inhabited by female crabs weighed between 9.68 and $32.22 \mathrm{~g}$. The wet weight of hosts with a female crab tended to be smaller than that of individuals without a crab or with a male crab in their alimentary canal (Fig. 2). No seasonal change (Fig. 2) or sexual difference in the wet weight of hosts without a crab was detected (Student's t-test, p > 0.05; males, $n=93$, mean $\pm 95 \%$ confidence interval $=23.96$ $\pm 1.24 \mathrm{~g}$; females, $\mathrm{n}=90$, mean $\pm 95 \%$ confidence inter$\mathrm{val}=22.41 \pm 1.13 \mathrm{~g}$ )

Pea crabs inhabiting hosts collected from the shallower bottom showed no seasonal change in their carapace width (Fig. 3), which was between 9.8 and $10.5 \mathrm{~mm}$ for males and between 9.9 and $12.1 \mathrm{~mm}$ for females. Female crabs tended to be slightly larger than between the number of eggs in a clutch $(y)$ and the wet weight $(x)$ of the host in which the ovigerous female crab was found $(y=872.4+3.59 x, n=37, r=0.0382$, $\mathrm{p}>0.05$ )

In late February, the proportion of ovigerous female crabs was $77 \%$ (Figs. 1 \& 3): $80 \%$ of the ovigerous female crabs had Stage I eggs on their pleopods, and the remainder carried Stage Ila eggs (Fig. 5). In April and May, all female crabs bore eggs (Figs. 1 \& 3), although there were some individuals carrying only a small number of eggs (Fig. 4). About $80 \%$ of the female crabs collected in April had Stage Ila eggs, while $70 \%$ of the crabs collected in May had Stage IIIa or IIIb eggs (Fig. 5). In addition, 1 female crab collected in May carried a few eggs at Stage IIIb and a large number of egg membranes left behind after the hatching of zoea, suggesting that the zoeae had been released into the alimentary canal of their host. In mid-June, 5 of 12 female crabs had a few undeveloped eggs on their pleopods.

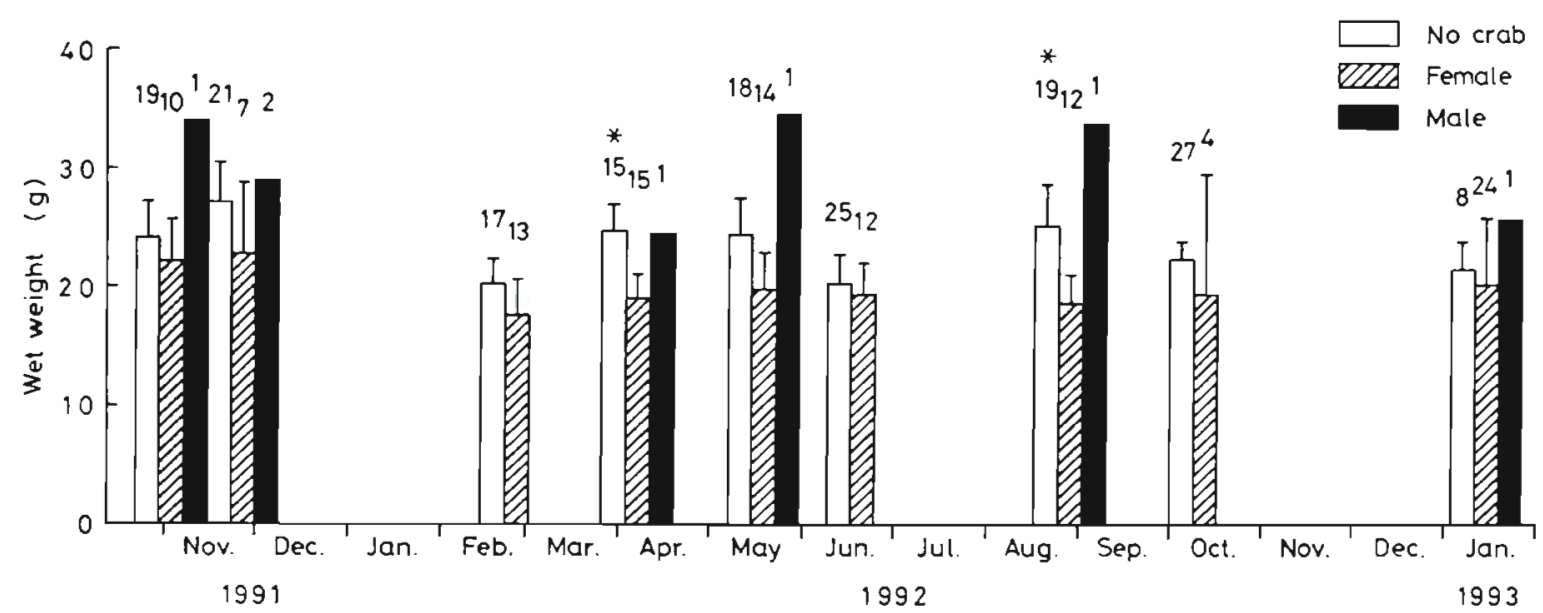

Fig. 2. Paracaudina chilensis. Seasonal variation in the wet weight of holothurians, both without pea crab Pinnixa tumida and with a male or a female crab in the alimentary canal, after removal of the gut contents specimens collected from the sandy bottom just below low water level of the spring tide. Error bars indicate $95 \%$ confidence interval and numerals above bars represent the number of holothurians sampled. *Significant difference (Student's $t$-test, $p<0.05$ ) between the wet weight of holothurians with no pea crab and that of specimens containing a female crab 


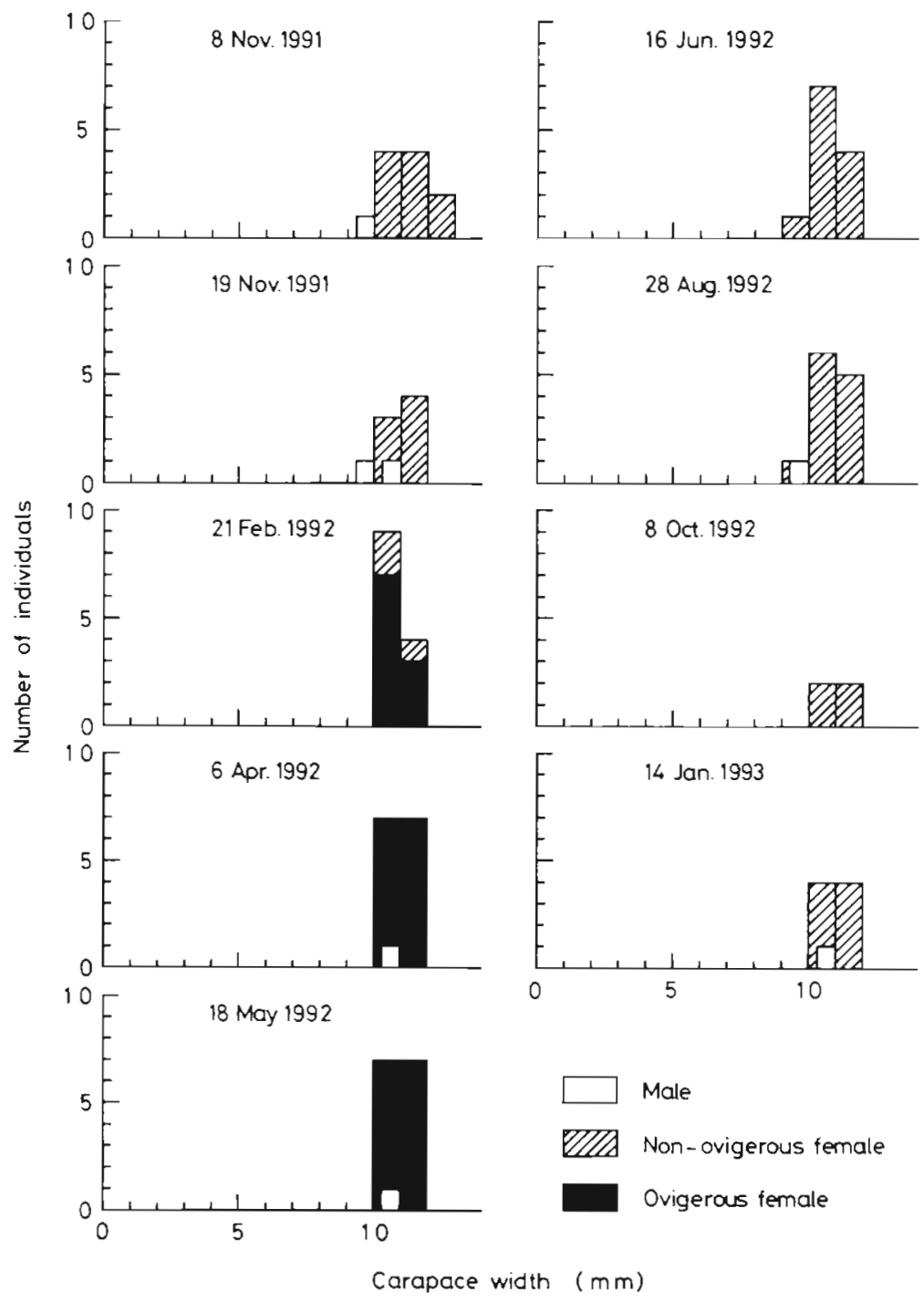

Fig. 3. Pinnixa tumida. Seasonal variation in the carapace width of pea crabs inhabiting holothurian Paracaudina chilensis collected from the sandy bottom just below the water level of the spring tide

Egg diameter increased gradually with the progress of egg development, and the number of eggs tended to decrease (Table 2).

In the 62 hosts collected at quarterly samplings from the deeper bottom, where smaller hosts predominated, only 4 crabs were found (Fig. 6) and these appeared in the larger hosts collected at the later samplings. Therefore, wet weights of hosts containing a pea crab were similar, regardless of whether they had been collected from the bottom in deeper or shallower water In addition, carapace widths of pea crabs collected from the deeper bottom corresponded to those of crabs collected from the shallower bottom (Figs, $3 \& 6$ ).

\section{Entrance into the host}

Pea crabs entered the host holothurians via the following process. Each crab searched for its host while moving on or, rarely, beneath the sand surface. The crab easily located the tip of the host's tail protruding from the sand's surface. If 2 crabs reached a single tip simultaneously, they fought near the tail, and one of them left. After reaching the tail's tip, the crab immediately or soon entered the sand alongside the tail (Fig 7A), or grabbed the tail's tip with its chelipeds and walking legs (Fig. 7B) The entrance began on the sand's surface or in the sand beneath the surface.

The crab frequently touched and/or clutched the tail using its chelipeds and walking legs in the sand and/or on the sand's surface. Occasionally the host extended its own tail tip farther above the sand's surface. At this time, the crab held on to the tail with its chelipeds and legs, and then drew the tip towards itself. Thereafter the crab put the dactyli of its walking legs on one side into the anus, opening the tip of the tail while holding on to the tail with the contralateral cheliped and legs. Subsequently the crab inserted its body forcibly and slowly with its walking legs and cheliped into the anus, gripping the inner surface of the cloaca with its inserted dactyli. In many cases, the crab kept its carapace and contralateral walking legs or only the contralateral walking legs buried in the sand, with the result that the tail of the host was bent into an inverse U-shape (Fig. 7C). The buried legs appeared to anchor the pea crab's body, thus enabling it to draw

Table 2. Pinnixa tumida. Changes in the egg diameter (mean $\pm 95 \%$ confidence interval) and clutch size (mean $\pm 95 \%$ confidence interval) at each developmental stage. $n$ : number of females carrying eggs in that developmental stage

\begin{tabular}{|lcrr|}
\hline $\begin{array}{l}\text { Developmental } \\
\text { stage }\end{array}$ & $\begin{array}{c}\text { Diameter } \\
(\mathrm{mm})\end{array}$ & $\begin{array}{c}\text { Clutch } \\
\text { size }\end{array}$ & $\mathrm{n}$ \\
\hline Stage I & $0.371 \pm 0.012$ & $1149.4 \pm 330.2$ & 10 \\
Stage Ila & $0.393 \pm 0.008$ & $930.6 \pm 224.7$ & 13 \\
Stage IIb & $0.411 \pm 0.024$ & $984.8 \pm 510.4$ & 4 \\
Stage IIIa & $0.411 \pm 0.021$ & $518.0 \pm 601.5$ & 5 \\
Stage IIlb & $0.423 \pm 0.018$ & $931.2 \pm 329.1$ & 5 \\
\hline
\end{tabular}




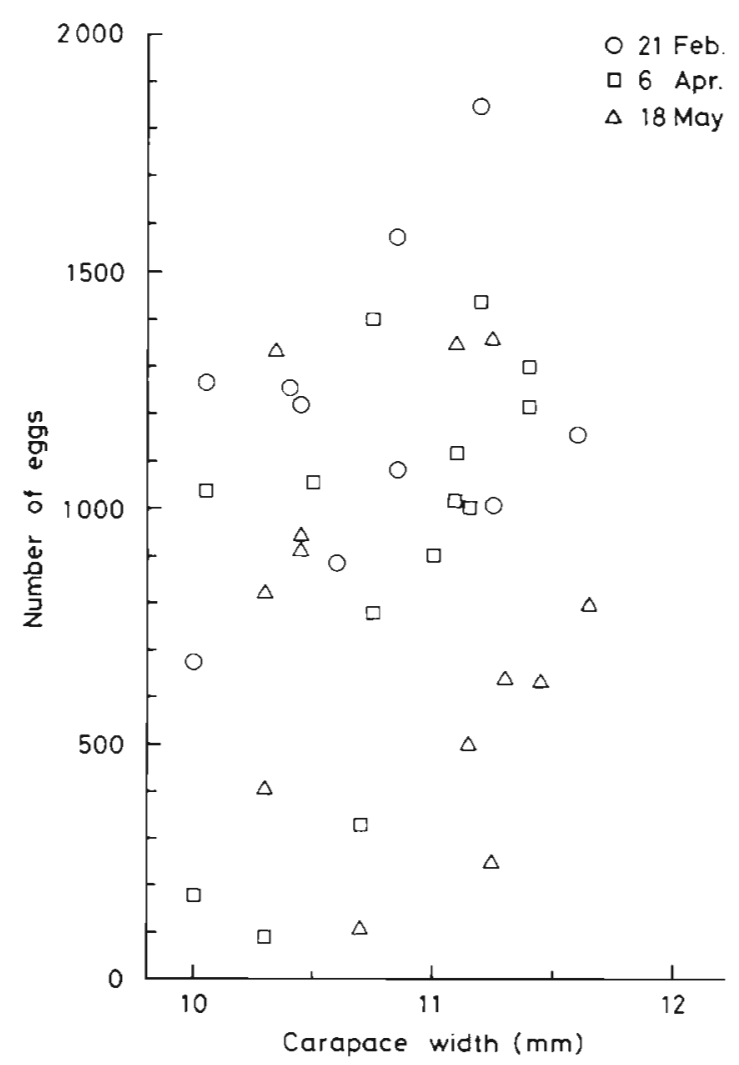

Fig. 4. PInnixa tumida. Relationship between the carapace width of ovigerous female pea crabs and the number of eggs carried

the host's tail towards itself and to insert its legs into the host's anus. The crab then inserted its carapace into the anus, which is normally smaller than the crab, and the host extended its tail (Fig. 7D), sometimes waving it. The crab extended its walking legs and/or remaining cheliped and began to enter the cloaca through the anus (Fig. $7 \mathrm{E}$ ), and then moved smoothly to the cloaca after entirely entering the anus (Fig. 7F).

The entrance process was observed only fragmentarily when the host buried its body entirely in the sand. The fragmentary observations did not differ widely from those of entrance on the sand's surface, indicating that the processes of entrance are basically similar both on and in the sand.

Host holothurians resisted the entrance of pea crabs by pulling the tail into the sand or pushing the tail further out into the water before and during the entrance procedure. Sometimes, the host waved its tail as the crab was entering its anus, thereby shaking off the crab.

Host holothurians entered by the pea crab sometimes shed seawater containing blood from the anus. In rare cases, a holothurian exited from the sand and died. In such cases, the crab came out of the alimentary canal of the host before the host died.
Pea crabs did not enter the host in vessels without sand, i.e. when the host was unburied. In such cases, the pea crab tried to enter the anus or the mouth, but the host moved about when the pea crab touched its body and/or inserted the dactyli of the walking legs, and entrance was never accomplished.

The pea crab entered hosts which either did or did not already have another crab in the alimentary canal (Table 3). When a pea crab entered a host holothurian without another crab in the alimentary canal, the time taken from the beginning of insertion of the dactyli of unilateral walking legs to the end of insertion of those on the opposite side tended to be longer for the female crabs, which have a larger carapace width than male crabs (Table 3). This tendency was also evident when the host already had another pea crab in its canal, although the duration of entrance tended to be shorter than that for hosts without a crab.

In several cases, the duration of the stay of 2 pea crabs in 1 host was shorter than 1.5 h (Table 4), suggesting that the pea crab solitarily inhabits its host. When both a male and a female crab had entered the same holothurian, the male crab was the crab which exited the host, regardless of whether it had entered before or after the female crab.

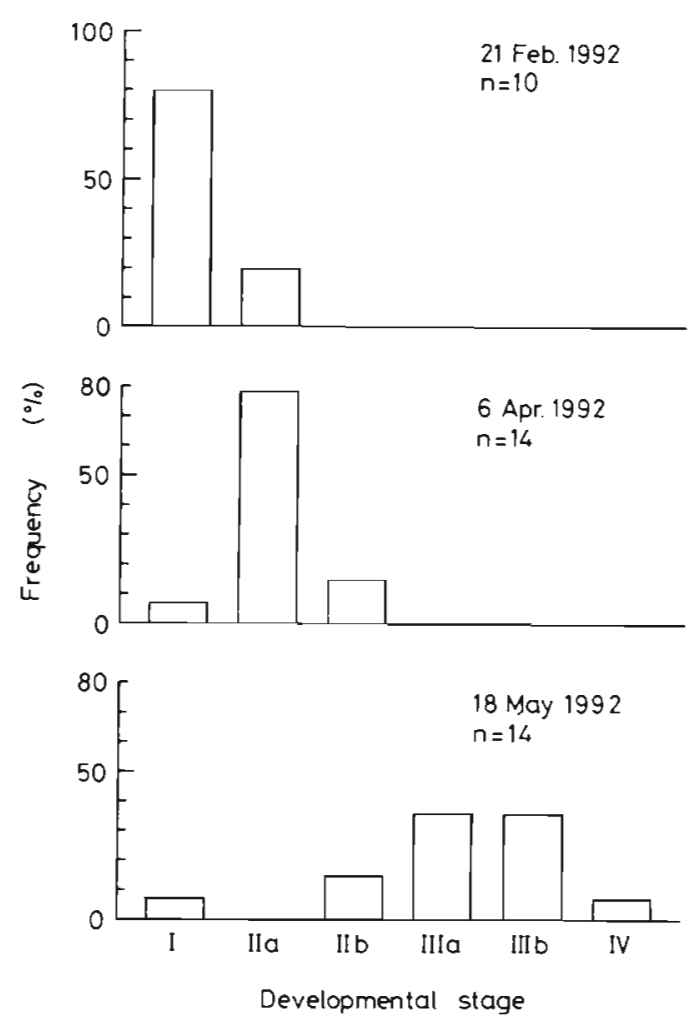

Fig. 5. Pinnixa tumida. Changes in the frequency distribution of female crabs carrying egg masses at each of 6 developmental stages during the breeding period 
Table 3. Pinnixa tumida. Time taken from the beginning of insertion of the dactyli of the walking legs on one side until completion of insertion of those on the opposite side, when mature pea crabs enter the alımentary canal of their host holothurian Paracaudina chilensis containing no or 1 pea crab. Carapace widths: male $=8.60 \mathrm{~mm}$, female $=11.10,11.65,12.00 \mathrm{~mm}$

\begin{tabular}{|c|c|c|c|}
\hline \multicolumn{2}{|c|}{ Without crab } & \multicolumn{2}{|c|}{ With crab } \\
\hline Male & Female & Male & Female \\
\hline$<21 \mathrm{~m} \mathrm{n}^{\mathrm{c}}$ & $52 \mathrm{~min}$ & $14 \mathrm{~min}$ & $34 \mathrm{~min}$ \\
\hline $1 \mathrm{~h} 4 \mathrm{~min}$ & $1 \mathrm{~h} 39 \mathrm{~min}$ & $3 \mathrm{~min}-20 \mathrm{~min}^{\circ}$ & $1 \mathrm{~h} 8 \min$ \\
\hline $1 \mathrm{~h} 35 \mathrm{~min}$ & 2 h 23 min -2 h 37 min $^{a}$ & $14 \min -34 \min ^{4}$ & $1 \mathrm{~h} 26 \mathrm{~min}$ \\
\hline & 3 h $21 \mathrm{~min}-5$ h $18 \min ^{a}$ & $<39 \min ^{\mathrm{d}}$ & $2 \mathrm{~h} 6 \min -3$ h $3 \mathrm{~min}^{\mathrm{a}}$ \\
\hline
\end{tabular}

"Beginning of insertion of the walking legs on one side, and/or the end of insertion of the thoracic legs on the remaining side, was carried out in the sand, and therefore the exact time could not be determined

Table 4. Pinnixa tumida. Duration of the simultaneous stay of 2 pea crabs in 1 host holothurian Paracaudina chlensis. First sex indicates the sex of the pea crab already present in the host, and second sex indicates the sex of the crab entering during the observation period. Exiting sex indicates the sex of the crab exiting the host holothurian

\begin{tabular}{|lllr|}
\hline First sex & Second sex & Exiting sex & Duration \\
\hline Male & Female & Male & $40 \mathrm{~min}$ \\
Female & Male & Male & $30 \mathrm{~min}$ \\
Female & Male & Male & $41 \mathrm{~min}$ \\
Female & Male & Male & $28 \mathrm{~min}-57 \mathrm{~min}^{\mathrm{d}}$ \\
Female & Male & Male & $2 \mathrm{~h} 37 \mathrm{~min}-3 \mathrm{~h} 25 \mathrm{~min}^{\mathrm{d}}$ \\
Female & Female & Female & $1 \mathrm{~h} 20 \mathrm{~min}$ \\
Female & Female & Female & $1 \mathrm{~h} 20 \mathrm{~min}$ \\
Female & Female & Female & $49 \mathrm{~min}-1 \mathrm{~h} 40 \mathrm{~min}^{\mathrm{a}}$ \\
antrance and/or exit was carried out in the sand, and \\
\hline \multicolumn{2}{|l}{ therefore exact time could not be determined } \\
\hline
\end{tabular}

\section{Feeding behavior and feeding habit}

When suspended particles which had been collected using plankton nets were supplied, the pea crab extended its second and third maxillipeds, spread out the well-developed feathery setae of the maxillipeds into a wide, spoon-shaped net, fanned them, and caught the suspended particles. The crab used its mouth parts to select the particles, and then fed on them (Table 5).

When fresh meat of host holothurians was supplied directly, feeding behavior of the pea crab was observed; the pea crab approached the meat, and then rubbed its body against the surface of the alimentary canal of the meat. Thereafter, it was observed that the mucus from the holothurian's body became attached to the crab's body, especially the carapace and the thoracic legs, which bear feather-like hairs. The crab scraped and collected the mucus on its walking legs and carapace using its chelipeds and walking legs, and subsequently ate the mucus after selection using its mouth parts. In addition, when the meat was supplied 'indirectly' (i.e. meat and crab were separated by the

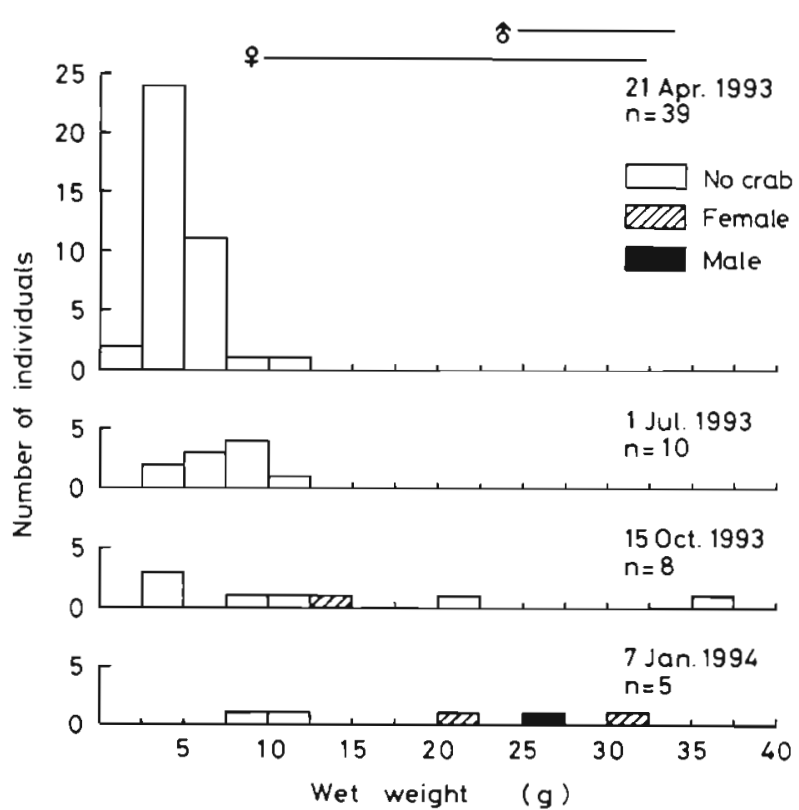

Fig. 6. Paracaudina chilensis. Seasonal variation in the wet weight of holothurians collected from the infra-littoral bottom, where smaller hosts predominated, after removal of gut contents. Carapace widths of pea crab Pinnixa tumida found in hosts were $11.55 \mathrm{~mm}$ (female) for October 1993 and 8.60 $\mathrm{mm}$ (male), $11.10 \mathrm{~mm}$ (female) and $12.00 \mathrm{~mm}$ (female) for January 1994. For comparison, horizontal lines in the upper part of the figure indicate the ranges of wet weight (after removal of gut contents) of holothurians inhabited by male and female pea crabs collected from the sandy bottom just below the low water level of the spring tide where larger hosts predominated $(\mathrm{n}=286$, mean weight $\pm 95 \%$ confidence interval $=22.19 \pm 0.70 \mathrm{~g}$ )

$5 \mathrm{~mm}$ mesh size net), the crab acted out its scraping and collecting movements, despite the absence of mucus on its body. From these observations, the feeding process of the crab was divided into 3 categories: (1) behavior for attaching mucus to its body by rubbing against the meat, (2) behavior for scraping and/or collecting mucus using the thoracic legs, regardless of the presence or absence of mucus on its body, presumably 
Table 5. Pinnixa tumida. Response of pea crab to food sources supplied. (+) Behavior or phenomenon observed, (-) behavior or phenomenon never observed

\begin{tabular}{|c|c|c|c|c|}
\hline Food source & s attachment & Mucus-collecting behavior & Feeding & Entering behavior \\
\hline Suspended particles & - & - & + & - \\
\hline Living host holothurian Paracaudina chilensis & - & - & - & + \\
\hline Living host holothurian (separated) & - & - & - & - \\
\hline Fresh meat of host holothurian & + & + & + & - \\
\hline Fresh meat of host holothurian (separated) & - & + & - & - \\
\hline Living non-host holothurian Apostichopus japonicus & $5-$ & - & - & + \\
\hline Living non-host holothurian (separated) & - & - & - & - \\
\hline Living bivalve Mactra chinensis & - & - & - & - \\
\hline Fresh meat of bivalve & - & - & - & - \\
\hline Living bivalve Mytilus edulis & - & - & - & - \\
\hline Fresh meat of bivalve & - & - & - & - \\
\hline
\end{tabular}

in response to odor cues, and (3) behavior for selecting the collected mucus and then feeding on it (Table 5).

When the living host holothurian was supplied directly, the pea crab tried to enter the host, but feeding behavior was never observed. When another living holothurian, Apostichopus japonicus, was supplied, the pea crab persistently clutched the holothurian with its walking legs, as if trying to enter it (Table 5) but did not enter.

The pea crab was entirely indifferent to the 2 species of living bivalves supplied and their fresh meat, and did not approach them (Table 5).

\section{DISCUSSION}

\section{Entrance}

Carapace widths of female crabs inhabiting host holothurians remained unchanged throughout the investigation, including the ovigerous period (Fig. 3). In addition, female crabs smaller than those of the mature size were never found in hosts collected from either shallower or deeper bottoms (Figs. $3 \& 6$ ). These results suggest that the female crab of this species is already mature when it enters its host, or matures just after entering. In fact, it was observed that only mature pea crabs (male or female) entered the host alimentary canal via the anus (Fig, 7).

The male crab, which is smaller than the female crab (Fig. 3), although sexual dimorphism is not remarkable, was able to enter the host in a shorter time than the female (Table 3). This means that the smaller immature female crab would be able to enter the host, suggesting that the timing of entrance into the host is decided individually rather than by the host.

Wells \& Wells (1961) investigated the pea crab Pinnaxodes floridensis inhabiting the endobenthic holo- thurian Theelothuria princeps on Florida, USA, beaches. They collected several juvenile crabs from the anterior part of the digestive system of their host and assumed that the crab enters at the juvenile stage. However, they did not refer to how the pea crab enters its host.

\section{Feeding habit}

Laboratory observations suggested that the pea crab feeds on suspended materials using the feathery setae of its maxillipeds while it lives freely outside the host holothurian, and feeds on the mucus secreted in the alimentary canal of the host when it lives inside the host's body (Table 5). It was also observed that, immediately after removal from the host's alimentary canal, crabs had attached mucus on their body, which was later eaten. Moreover, the crabs had no particles, such as fine sand, silt and clay, in their intestines, although a large part of the alimentary canal of the host was crammed with fine sand and seawater (authors' pers. obs.). These observations support the contention that the crabs usually feed on the mucus of the alimentary canal while inhabiting their host. In addition, the 2 feeding habits of this pea crab appear to support the above assumption that the female crabs enter their hosts just before and/or after maturation.

Some species of pinnotherid crabs inhabiting the mantle cavity of host bivalves feed on the food strings of the host, which are formed by mucus secreted from the gills and suspended particles captured by the gills (Coupin 1894, Orton 1921, Stauber 1945, MacGinitie \& MacGinitie 1949, Pearce 1966a, Kruczynski 1975), In addition, the pea crab Opisthopus transversus inhabiting the pallial grooves of the chiton Cryptochiton stellexi is considered to feed on the mucus in the grooves and its contents, based on the presence of pallial 

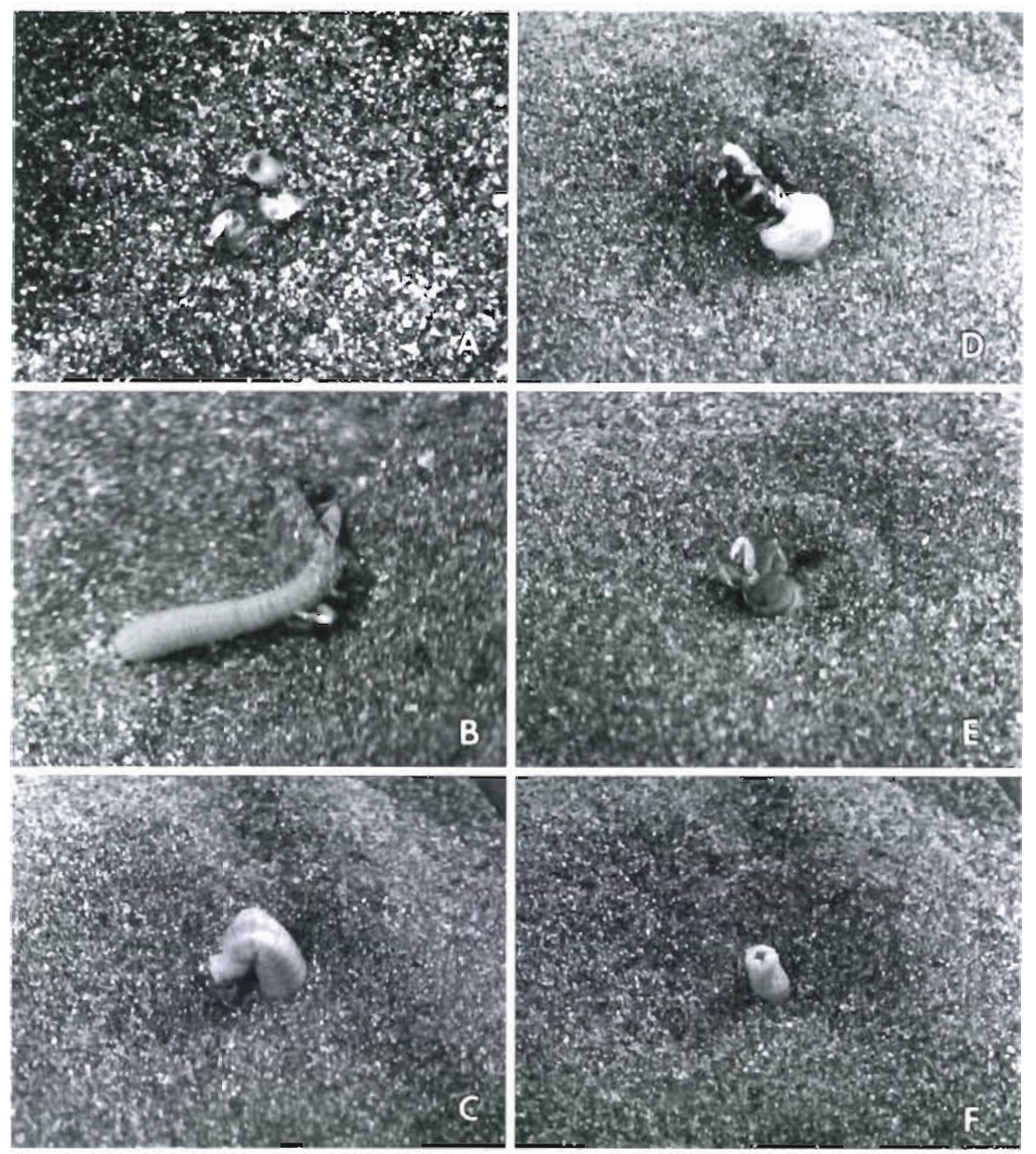

Fig. 7. Paracaudina chilensis and Pinnixa tumida. (A) Tip of the tail of a host holothurian protruding from the sand's surface, and a pea crab burying its body in the sand alongside the host's tail. (B) Pea crab holding the host's tail, which projects some distance from the sand. (C) Pea crab inserting the dactyli of its walking legs on one side into the host's anus at the opening of the tail tip, while about half of its body is buried in the sand. (D) Pea crab inserting its walking legs on one side into the host's anus, in which the body of the crab is suspended. (E) Pea crab with half of its body inserted into the host's anus. (F) Tip of the host's tail just after entry by a pea crab

mucus surrounding the crab's body (Webster 1968). This mucus feeding habit may be common to all pinnotherid crabs.

The species of pinnotherid crabs which live in bivalves adapt their life history and feeding habit to their hosts (Atkins 1926, 1955, 1958, Christensen 1958. Christensen \& McDermott 1958, Pearce 1966a, Jones $1977 \mathrm{a}$, b). Crabs of the genus Dissodactylus settle on their hosts (irregular echinoids) at an early stage of post-larval life, and depend on their hosts as a food source (Telford 1982, Bell \& Stancyk 1983). On the other hand, Pinnixa tumida enters its host holothurians after or just before maturity, and shows 2 different feeding habits depending on its position outside or within the alimentary canal of the host. Thus, pea crabs may facultatively associate with the host holothurians, unlike those species living in host bivalves and on host echinoids.

\section{Relationship between the pea crab and its host}

In the laboratory, several host holothurians entered by a crab sometimes bled from their anus, came out of the sand and, on very rare occasions, died on the sand surface. In the field, hosts that had emerged on the sand surface were also observed occasionally. Field surveys conducted on the shallower bottom, where larger hosts predominated, showed that the wet weight of hosts bearing a female crab in their alimen- 
tary canal tended to be lower than those without a crab or with a male crab (Fig. 2). On the other hand, hosts with a lower wet weight, which were collected from the deeper bottom, did not contain pea crabs (Figs, 2 \& $6)$. These results suggest that the female crab damages the host, and/or delays its growth.

The females of Pinnotheres ostreum, which as juveniles enter the mantle cavity of oysters, affect the respiratory and feeding activity of their hosts by eroding part of the gill (Stauber 1945) and delaying the host's growth (Christensen \& McDermott 1958). Pinnotheres modiolicola also decreases the weight of its host (Lopez 1982), and females of Pinnotheres pholadis reduce the size of their host's gonad (Yoo \& Kajihara 1985). These reports appear to support the above contention that the females of Pinnixa tumida also delay the growth of their hosts.

This pea crab solitarily inhabited each large host holothurian in the field. The solitary presence of the symbiont in the host organism is due to interaction among conspecifics, i.e. competition for hosts as a living space and/or food source (Bell 1988). When the crab entered a host already bearing another crab in its alimentary canal, 1 of the 2 crabs exited the host in a short time (Table 4). In addition, it was observed that when 2 crabs approached the same tail tip they fought, suggesting that similar competition occurs between the 2 crabs in the alimentary canal of the host. These laboratory observations may explain the solitary occurrence of this species in the field.

Almost all of the pea crabs collected from their host holothurians were females (Table 3). Pinnaxodes floridensis, which inhabits another species of holothurian, showed the same skewed sex ratio (Wells \& Wells 1961). It was assumed that the difference in the sex ratio is caused by the wandering of male crabs from host to host in search of female crabs, and the high mortality of male crabs that occurs during their search for host holothurians. The male crab of the present species, Pinnixa tumida, may also wander from host to host in search of female crabs, and thus may stay a relatively shorter time in each host it enters. This is consistent with the fact that the weight of hosts did not differ between those bearing a male crab and those without a crab, in contrast to hosts bearing a female crab (Fig. 2). In addition, it was frequently observed that the female pea crab left weakened hosts which had come out of the sand. This observation suggests that female crabs also transfer repeatedly to another host once the original host has become weakened.

\section{Reproduction}

Ovulation of this pea crab was considered to occur in February, when the seawater temperature is at its low- est (Fig. 1), since ovigerous females appeared in late February 1992, and still had not appeared or reappeared by mid-January 1993 (Fig. 1), and the eggs attached to their pleopods were at an early developmental stage in late February 1992 (Fig. 5). Only 1 female crab releasing zoeae was collected in mid-May (Fig. 5). Nevertheless, half of the ovigerous females had Stage IIb and IIIa eggs, simultaneously. In midJune, 5 of 12 female crabs had only a few undeveloped eggs on their pleopods. These findings indicate that release of zoeae from this pea crab generally occurred in early June. That is, the ovigerous period of this pea crab was considered to last about $3.5 \mathrm{mo}$, from midFebruary to early June.

The water temperature during the ovigerous period was between 2 and $16^{\circ} \mathrm{C}$, averaging about $10^{\circ} \mathrm{C}$ (Fig. 1). During this period, the eggs attached to pleopods developed slowly and synchronously in almost all of the ovigerous females (Fig. 5), showing that this pea crab has a breeding cycle with an ovigerous period of about $3.5 \mathrm{mo} \mathrm{yr}^{-1}$, although the numbers of eggs borne by each female varied widely (Fig. 4). The ovigerous period estimated in this study coincides with that of Telmessus acutidens (Atelecyclidae; Brachyura), which carries eggs within the same range of seawater temperature for about $4 \mathrm{mo}$, and is in accord with the contention that the ovigerous periods of brachyura are related roughly to the water temperature (Okamoto 1991).

Clutch size of Pinnixa tumida with carapace widths of between 10 and $11.65 \mathrm{~mm}$ varied widely between 93 and 1846 eggs (Fig. 4, Table 6). In crabs of the genus Dissodactylus living on irregular echinoids, clutch sizes are smaller; this may be due to the fact that their body size is smaller than that of $P$. tumida. On the other hand, pinnotherid crabs living in bivalves have a larger clutch size, but the size of their eggs does not differ significantly from that of $P$. tumida. Part of the egg clutches of these crabs protrude from the coverage of the abdomen (Silas \& Alagarswami 1967, Jones 1977a). In contrast, the ovigerous females of Dissodactylus mellitae completely cover their clutches, and clutch size is limited by the extent of abdominal coverage provided to protect the eggs from being injured by echinoid spines (Bell \& Stancyk 1983). The clutch of $P$. tumida was also completely covered by the abdomen. The small clutch size may be related to the internal condition of the alimentary canal of the host, which contains fine sand, since any protruding eggs might be removed by the sand during transfer in the alimentary canal.

Pea crabs inhabiting the mantle cavity of bivalves after entering at the juvenile stage adapt their mode of life throughout their whole life span, and continue to weakly damage their hosts during their period of habitation. On the other hand, Pinnixa tumida enters its 


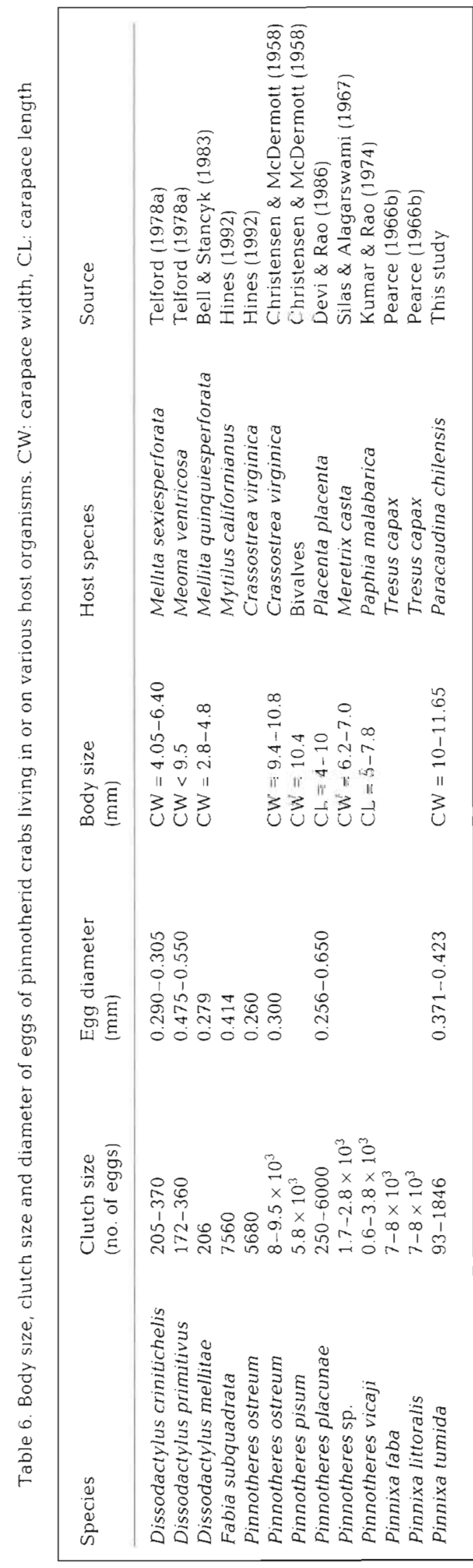

host holothurian after maturity or just before maturity. The pea crabs, especially females, are considered to damage the host and to transfer repeatedly from damaged and weakened hosts to new hosts. The association between $P$. tumida and its host may therefore be undeveloped in comparison with those of pea crabs inhabiting bivalves and their hosts.

Pinnixa tumida uses 2 different feeding habits, depending on its position outside or within the alimentary canal of the host, suggesting that the pea crab acquires a mucus feeding habit secondary to a suspension feeding habit. In addition, other pea crabs inhabiting bivalves feed on the mucus secreted from the gills of their hosts, which contains suspended particles captured by the gills. The acquisition of a mucus feeding habit by pinnotherid crabs may further be associated with various types of host organism, and subsequently speciation in this group.

\section{LITERATURE CITED}

Atkins D (1926) The moulting stages of the pea-crab (Pinnotheres pisum). J Mar Biol Assoc UK 14:475-493

Atkins D (1955) The post-embryonic development of British Pinnotheres (Crustacea). Proc Zool Soc Lond 124:687-715

Atkins D (1958) British pea-crabs (Pinnotheres). Nature 181: 1087

Bell JL (1984) Changing residence: dynamics of the symbiotic relationship between Dissodactylus mellitae Rathbun (Pinnotheridae) and Mellita quinquesperiorata (Leske) (Echinodermata). J Exp Mar Biol Ecol 82:101-115

Bell JL (1988) Distribution and abundance of Dissodactylus mellitae Rathbun (Pinnotheridae) on Mellita quinquiesperforata (Leske) (Echinodermata). J Exp Mar Biol Ecol 117:93-114

Bell JL, Stancyk SE (1983) Population dynamics and reproduction of Dissodactylus mellitae (Brachyura: Pinnotheridae) on its sand dollar host Mellita quinquiesperforata (Echinodermata). Mar Ecol Prog Ser 13:141-149

Christensen AM (1958) On the life history and biology of Pinnotheres pisum. Proc 15th Int Zool Congr (Sect II) Paper 15:267-270

Christensen AM, McDermott JJ (1958) Life-history and biology of the oyster crab, Pinnotheres ostreum Say. Biol Bull $144: 146-179$

Coupin H (1894) Sur l'alimentation de deux commensaux (Nereilepas et Pinnotheres). CR Acad Sci Paris 119: $540-543$

Devi SL, Rao KH (1986) Some aspects of blology of the peacrab Pinnotheres placunde Hornell and Southwell. Proc Indian Natl Sci Acad Part B Biol Sci 52:455-459

Gray IE (1961) Changes in abundance of the commensal crabs of Chaetopterus. Biol Bull 120:353-359

Griffith $H$ (1987) Phylogenetic relationships and evolution in the genus Dissodactylus Smith, 1870 (Crustacea: Brachyura: Pinnotheridae). Can J Zool 65:2292-2310

Hines AH (1992) Constraint on reproductive output in brachyuran crabs: pinnotherids test the rule. Am Zool 32 $503-511$

Jones JB (1977a) Post-planktonic stages of Pinnotheres novaezelandiae Filhol, 1886 (Brachyura: Pinnotheridae) NZ J Mar Freshwater Res 11:145-158 
Jones JB (1977b) Natural history of the pea crab in Wellington Harbour, New Zealand. NZ J Mar Freshwater Res 11: $667-676$

Jones MB (1980) Reproductive ecology of the estuarine burrowing mud crab Helice crassa (Grapsidae). Estuar Coast Mar Sci 2:433-443

Kruczynski WL (1975) A radioactive tracer study of food uptake by Pinnotheres maculatus in Molluscan hosts. Biol Bull 148:60-67

Kumar LK, Rao KV (1974) Life-cycle of the pea-crab, Pinnotheres vicaji Chhapgar, infesting the clam, Paphia malabarica. Indian J Mar Sci 3:165-172

Lopez MDG (1982) Pea crab infestation in the brown mussel, Modiolus metcalfei Hanley. Kalikasan 11:98-110

MacGinitie GE, MacGinitie N (1949) Natural history of marine animals. McGraw-Hill, Inc, New York

Morisita M (1959) Measuring of the dispersion of individuals and analysis of the distributional patterns. Mem Fac Sci Kyushu Univ Ser E Biology 2:215-235

Okamoto K (1991) On the development, hatching and culture of eggs of the giant spider crab, Macrocheira kaempferi. Bull Shizuoka Pref Fish Exp Stn 26:21-33 (in Japanese with English abstract)

Orton JH (1921) The mode of feeding and sex phenomena in the pea crab (Pinnotheres pisum). Nature 106:533-534

Pearce JB (1966a) The biology of the mussel crab, Fabia subquadrata, from the waters of the San Juan Archipelago, Washington. Pac Sci 20:3-35

Pearce JB (1966b) On Pinnixa faba and Pinnixa littoralis (Decapoda: Pinnotheridae) symbiotic with the clam, Tresus capax (Pelecypoda: Mactridae). In: Barnes $H$ (ed) Some contemporary studies in marine science. Allen Unwin Ltd, London, p 565-589

Sakai T (1976) Crabs of Japan and the adjacent seas. Kodansha, Tokyo

Schmitt WL, McCain JC, Davidson ES (1973) Decapoda I, Brachyura I, Family Pinnotheridae. In: Gruner HE, Holthuis LB (ed) Crustaceorum Catalogus: part 3. W. Junk, Den Haag, p 1-160

Silas EG, Alagarswami K (1967) On the instance of parasitisation by the pea-crab (Pinnotheres sp.) on the backwater clam (Meretrix casta [Chemnitz]) from India, with a review of the work on the systematics, ecology, and ethology of pea-crabs of the genus Pinnotheres Latreille. Symposium on Crustacea, Mar Biol Assoc [ndia 2(III):1161-1227

This article was submitted to the editor
Stauber LA (1945) Pinnotheres ostreum, parasitic on the American oyster, Ostrea (Gryphaea) virginica. Biol Bull 88:269-291

Stimpson W (1858) Prodromus descriptions animalium evertebratorum quae in Expeditione ad Oceanum Pacificum Septentrionalem, a Republica Federata missa, Cadwaladaro Ringgold et Johanne Rodgers Ducibus, observavit et descripsit. Proc Acad NatI Sci Philadelphia 10: $31-40$

Tadokoro T, Watanabe $S$ (1928) Chemical studies on sex differences of blood protein in Caudina chilensis J Muller. Sci Rep 4th Ser Biol Tohoku Imp Univ 3:535-545

Telford M (1978a) Post-larval growth in two species of Dissodactylus (Brachyura: Pinnotheridae). Bull Mar Sci 28: $645-650$

Telford M (1978b) Distribution of two species of Dissodactylus (Brachyura: Pinnotheridae) among their echinoid host populations in Barbados. Bull Mar Sci 28:651-658

Telford $M$ (1982) Echinoderm spine structure, feeding and host relationships of four species of Dissodactylus (Brachyura: Pinnotheridae). Bull Mar Sci 32:584-594

Webster SK (1968) An investigation of the commensals of Cryptochiton stelleri (Middendorff, 1846) in the Monterey Peninsula area, California. Veriger 11:121-125

Wells HW, Wells MJ (1961) Observations on Pinnaxodes floridensis, a new species of pinnotherid crustacean commensal in holothurians. Bull Mar Sci Gulf Caribb 11:267-279

Welis WW (1940) Ecological studies on the Pinnotherid crabs of Puget Sound. Univ Wash Publ Oceanogr 2:19-50

Yamanouchi T (1926) Some preliminary notes on the behavior of the Holothurian, Caudina chilensis (J. Muller). Sci Rep 4th Ser Biol Tohoku Imp Univ 2:85-91

Yamanouchi $T$ (1929a) Notes on the behavior of the Holothurian, Caudina chilensis (J. Muller). Sci Rep 4th Ser Biol Tohoku Imp Univ 4:73-115

Yamanouchi $T$ (1929b) Statistical study on Caudina chilensis (J. Muller). Sci Rep 4th Ser Biol Tohoku Imp Univ 4: $335-359$

Yokoya Y (1928) Report of the biological survey of Mutsu Bay. 10. Brachyura and crab-shaped Anomura. Sci Rep 4th Ser Biol Tohoku Imp Univ 3:757-784

Yoo MS, Kajihara T (1985) The effect of the pea crab (Pinnotheres pholadis) on the reproductive capacity of the blue mussel (Mytilus edulis galloprovincialis). Bull Korean Fish Soc 18:581-585

Manuscript first received: September 25, 1996 Revised version accepted: January 24, 1997 